\title{
Photo-stable perovskite solar cells with reduced interfacial recombination losses using a $\mathrm{CeO}_{x}$ interlayer
}

\author{
Xiaoqiang Shi ${ }^{1}$, Ye $\mathrm{Tao}^{1}$, Zhuoxin $\mathrm{Li}^{1}$, Huirong Peng ${ }^{1}$, Molang Cai ${ }^{1,2^{*}}$, Xuepeng Liu ${ }^{1}$, \\ Zhongyan Zhang ${ }^{1}$ and Songyuan Dai ${ }^{1,2^{*}}$
}

\begin{abstract}
Despite demonstrating remarkable power conversion efficiencies (PCEs), perovskite solar cells (PSCs) have not yet achieved their full potential. In particular, the interfaces between the perovskite and charge transport layers account for the vast majority of the recombination losses. Interfacial contact and band alignment between the lowtemperature-processed $\mathrm{TiO}_{2}$ electron transport layer (ETL) and the perovskite are essential to minimize nonradiative recombination losses. In this study, a $\mathrm{CeO}_{x}$ interlayer is employed to modify the perovskite $/ \mathrm{TiO}_{2}$ interface, and the charge transport properties of the devices are investigated. The bilayer-structured $\mathrm{TiO}_{2} / \mathrm{CeO}_{x}$ ETL leads to the modification of the interface energetics, resulting in improved electron extraction and reduced nonradiative recombination in the PSCs. Devices based on $\mathrm{TiO}_{2} / \mathrm{CeO}_{x}$ ETL exhibit a high open-circuit voltage $\left(V_{o c}\right)$ of $1.13 \mathrm{~V}$ and an enhanced PCE of more than $20 \%$ as compared with $V_{o c}$ of $1.08 \mathrm{~V}$ and a PCE of approximately $18 \%$ for $\mathrm{TiO}_{2}$-based devices. Moreover, PSCs based on $\mathrm{TiO}_{2} /$ $\mathrm{CeO}_{x}$ ETL maintain over $88 \%$ of their initial PCEs after light illumination for $300 \mathrm{~min}$, whereas PSCs based on $\mathrm{TiO}_{2}$ ETL almost failed. This study provides an efficient strategy to enhance the PCE and stability of PSCs based on a lowtemperature-processed $\mathrm{TiO}_{2}$ ETL.
\end{abstract}

Keywords: perovskite solar cell, interface passivation, recombination, light stability, $\mathrm{CeO}_{x}$

\section{INTRODUCTION}

In the past decade, huge efforts have been devoted worldwide to understanding and improving the performance of perovskite solar cells (PSCs), which already outperform other conventional thin-film photovoltaic technologies [1-5]. Recently, the highest certified power conversion efficiency (PCE) of PSCs has reached 25.5\% [6]. It is well established that further improvements in the performance of PSCs will require suppression of nonradiative charge recombination (trap-assisted charge recombination) losses to unlock the full thermodynamic potential of PSCs [7-9]. Charge transport layers (CTLs) are key components of high-performance PSCs; however, interface defects and energy level misalignments can induce additional nonradiative recombination pathways, which limit the open-circuit voltage $\left(V_{\mathrm{oc}}\right)$ and fill factor (FF) of PSCs. CTLs/perovskite interfaces dominate the nonradiative recombination in efficient PSCs [9]. Therefore, to realize the full thermodynamic potential of the perovskite absorber, the formation of a good contact for the CTLs/perovskite interface is essential.

The addition of interlayers between the CTLs and perovskite absorber has proven to be an efficient method to mitigate interfacial recombination losses [10-12]. For the interface between the electron transport layer (ETL) and perovskite, a broad range of interlayer materials, including metal oxides, conjugated polymers, small molecules, and fullerenes, has been reported [13-15]. Among these, metal-oxide interlayers are frequently used in PSCs owing to their good chemical stability, which endows the interlayers with robust (solvent-resistant) properties [1620]. $\mathrm{TiO}_{2}$ films annealed under high temperature are widely employed as the ETL, with the aim of achieving high-performance PSCs. However, low-temperatureprocessed $\mathrm{TiO}_{2}$-based planar PSCs exhibit low efficiencies due to intrinsic problems such as the unsuitable conduction band energy and low electron extraction ability of

\footnotetext{
${ }^{1}$ Beijing Key Laboratory of Novel Thin-Film Solar Cells, North China Electric Power University, Beijing 102206, China

${ }^{2}$ State Key Laboratory of Alternate Electrical Power System with Renewable Energy Sources, North China Electric Power University, Beijing 102206, China

*Corresponding authors (emails: molangcai@ncepu.edu.cn (Cai M); sydai@ncepu.edu.cn (Dai S))
} 
$\mathrm{TiO}_{2}$. Several attempts have been made at modifying the $\mathrm{TiO}_{2}$ ETL in planar PSCs using metal-oxide interlayers to reduce the interface recombination losses. For instance, the insertion of a $\mathrm{ZnO}$ interlayer between the $\mathrm{TiO}_{2}$ layer and perovskite reduces interfacial recombination due to the proper energy alignment [21,22]. Thermal instability has been observed in $\mathrm{ZnO}$-based PSCs and is attributed to the deprotonation of the organic cation caused by the basic nature of the $\mathrm{ZnO}$ surface [23]. Moreover, an enhanced charge extraction ability and suppressed carrier recombination at the $\mathrm{TiO}_{2}$ /perovskite interface were also achieved using $\mathrm{SnO}_{2}$ as the interlayer [24,25]. In addition to interfacial charge recombination, another issue associated with $\mathrm{TiO}_{2}$-based PSCs is the photo-induced device degradation [26]. These problems stimulate further research toward exploring efficient ETLs with favored interface contact and good light stability.

Here, we propose an ETL comprising an amorphous $\mathrm{CeO}_{x}$ interlayer on top of a $\mathrm{TiO}_{2}$ compact layer fabricated via a low-temperature solution process. Furthermore, we perform a comprehensive study on planar PSCs based on the $\mathrm{TiO}_{2} / \mathrm{CeO}_{x}$ double layer. It is shown that the band alignment, electron extraction, PCE, hysteresis, and stability of PSCs can be significantly improved using the bilayer-structured $\mathrm{TiO}_{2} / \mathrm{CeO}_{x}$ ETL compared with the pure $\mathrm{TiO}_{2}$ ETL. Owing to the reduced interfacial charge recombination, solar cells based on the $\mathrm{TiO}_{2} / \mathrm{CeO}_{x}$ ETL demonstrate a maximum $V_{\text {oc }}$ of $1.13 \mathrm{~V}$ with $300 \mathrm{mV}$ potential loss compared with the $\mathrm{TiO}_{2}$-based cell $(1.08 \mathrm{~V}$ and $520 \mathrm{mV}$, respectively). The enhancement of $V_{\mathrm{oc}}$, together with the increase in FF (from $\sim 74 \%$ to $~ 76 \%$ ), enables a PCE improvement from $\sim 18 \%$ to more than $20 \%$. Moreover, thanks to the presence of the $\mathrm{CeO}_{x}$ interlayer, the PSCs exhibit a significantly improved light stability.

\section{EXPERIMENTAL SECTION}

\section{Materials}

Fluorine-doped tin-oxide (FTO) glasses $\left(\leq 15 \Omega \mathrm{sq}^{-1}\right)$ were purchased from South China Science \& Technology Company Limited. Titanium(IV) chloride $\left(\mathrm{TiCl}_{4}\right)$ and titanium diisopropoxide bis(acetylacetonate) were obtained from Sigma-Aldrich. Cerium(III) acetylacetonate hydrate was purchased from 9 Ding Chemistry. Methylammonium iodide (MAI) and lead(II) iodide $\left(\mathrm{PbI}_{2}\right)$ were purchased from TCI. 2,2',7,7'-Tetrakis-(N,N-di-p-methoxyphenylamine) $9,9^{\prime}$-spirobifluorene (Spiro-OMeTAD), 4-tert-butylpyridine $(t \mathrm{BP}), \quad$ lithium bis(trifluoromethanesulfonyl)imide (Li-TFSI), and tris $(2-(1 \mathrm{H}-$
pyrazol-1-yl)-4-tert-butylpyridine)-cobalt(III) tris(bis(trifluoromethylsulfonyl)imide) (FK209) were purchased from Xi'an Polymer Light Technology Corp. Anhydrous solvents, such as dimethylformamide (DMF), dimethyl sulfoxide (DMSO), chlorobenzene, ethanol, benzyl alcohol, diethyl ether, isopropanol, and acetonitrile were obtained from Alfa Aesar. All the chemicals were used as received without further purification.

\section{Device fabrication}

The pre-patterned FTO substrates were sequentially cleaned with saturated sodium hydroxide ethanol solution, deionized water, and ethanol and then exposed to UV-ozone for $15 \mathrm{~min}$. For the $\mathrm{TiO}_{2} \mathrm{ETL}, 100 \mu \mathrm{L}$ of the colloidal $\mathrm{TiO}_{2}$ nanocrystal solution was spin-coated onto the FTO substrate and annealed on a hot plate at $150^{\circ} \mathrm{C}$ for $30 \mathrm{~min}$ in ambient air. For the $\mathrm{CeO}_{x}$ interlayer, $100 \mu \mathrm{L}$ of the precursor solution was spin-coated onto the $\mathrm{TiO}_{2}$ substrate and annealed at $150^{\circ} \mathrm{C}$ for $30 \mathrm{~min}$. All ETLs were exposed to UV-ozone for $15 \mathrm{~min}$ prior to the deposition of the active layer. The perovskite layer was prepared from a precursor solution containing $1.4 \mathrm{~mol} \mathrm{~L}^{-1}$ of $\mathrm{MAPbI}_{3}$ in a mixed solvent of DMF and DMSO, with the volume ratio of DMF to DMSO being 1:4. The perovskite precursor solution was spin-coated onto different substrates via a consecutive two-step spincoating process, at 1200 and $4200 \mathrm{rpm}$ for 10 and $30 \mathrm{~s}$, respectively. During the second step, $120 \mu \mathrm{L}$ of chlorobenzene was poured onto the spinning substrate $10 \mathrm{~s}$ prior to the end of the spinning process. The films were then annealed on a hotplate at $100^{\circ} \mathrm{C}$ for $15 \mathrm{~min}$. Once being cooled to room temperature, Spiro-OMeTAD was deposited on top of the perovskite layer via spin-coating at $4000 \mathrm{rpm}$ for $30 \mathrm{~s}$. The Spiro-OMeTAD solution was prepared by dissolving $73.53 \mathrm{mg}\left(60 \mathrm{mmol} \mathrm{L}^{-1}\right)$ of SpiroOMeTAD in $1 \mathrm{~mL}$ of chlorobenzene, with the addition of $29.30 \mu \mathrm{L} \quad\left(200 \mathrm{mmol} \mathrm{L}^{-1}\right)$ of $t \mathrm{BP}$ and $17.23 \mu \mathrm{L}$ $\left(30 \mathrm{mmol} \mathrm{L}^{-1}\right)$ of Li-TFSI solution $(500 \mathrm{mg} \mathrm{Li}$-TFSI in $1 \mathrm{~mL}$ acetonitrile). Next, $6.78 \mu \mathrm{L}\left(1.8 \mathrm{mmol} \mathrm{L}^{-1}\right)$ of FK209 solution (400 mg FK209 in $1 \mathrm{~mL}$ acetonitrile) was added to the Spiro-OMeTAD solution; the molar ratio for FK209 and Spiro-OMeTAD was 0.03. Finally, an 80-nm gold layer was thermally evaporated on top of the device.

\section{Characterizations}

The morphology and crystal structure of the perovskite films were characterized via scanning electron microscopy (SEM, SU8010, Hitachi) and X-ray diffraction (XRD, Smartlab SE, Rigaku), respectively. The absorption spectra of the perovskite films were measured using a 
UV-Vis spectrometer (UV-3600Plus, Shimadzu). X-ray photoelectron spectroscopy (XPS) and ultraviolet photoelectron spectroscopy (UPS) were performed using a multifunctional photoelectron spectrometer (ESCALAB 250Xi, Thermo Scientific). Steady-state photoluminescence (PL) was performed using a home-built system. Current density-voltage $(J-V)$ curves were recorded using a Keithley 2400 source meter under simulated sunlight from a Newport AAA solar simulator.

\section{RESULTS AND DISCUSSION}

Preparation of the low-temperature solution-processed $\mathrm{TiO}_{2}$ and $\mathrm{TiO}_{2} / \mathrm{CeO}_{x}$ ETLs is shown schematically in Fig. 1a. The $\mathrm{TiO}_{2}$ nanocrystals were synthesized following a modified nonhydrolytic sol-gel method [27], whereas the $\mathrm{CeO}_{x}$ precursor solution was obtained by dissolving cerium(III) acetylacetonate hydrate in ethanol. All experimental details are provided in the experimental section. The surface and cross-sectional morphologies of the $\mathrm{TiO}_{2}$ and $\mathrm{TiO}_{2} / \mathrm{CeO}_{x}$ ETLs are shown in Fig. 1b-e. As can be seen from Fig. 1b, c, negligible difference can be observed between the surface topographies of the $\mathrm{TiO}_{2}$ and $\mathrm{TiO}_{2} / \mathrm{CeO}_{x}$ ETLs, indicating the presence of an ultra-thin
$\mathrm{CeO}_{x}$ interlayer. To confirm this, the SEM image of the $\mathrm{FTO} / \mathrm{CeO}_{x}$ film is shown in Fig. S1. The morphology of the FTO polycrystalline layer can be clearly distinguished after being covered with a thin $\mathrm{CeO}_{x}$ layer, in agreement with previous study [28]. XRD patterns show negligible difference between the $\mathrm{TiO}_{2}$ and $\mathrm{TiO}_{2} / \mathrm{CeO}_{x}$ films (Fig. S2), indicating that the low-temperature solutionprocessed $\mathrm{CeO}_{x}$ interlayer is amorphous. From the crosssectional view (Fig. 1d, e), it can be seen that the surface roughness of the $\mathrm{FTO} / \mathrm{TiO}_{2}$ film reduced after the introduction of the $\mathrm{CeO}_{x}$ interlayer. Atomic force microscopy measurements were performed to understand the influence of the $\mathrm{CeO}_{x}$ interlayer on the surface roughness. As shown in Fig. S3, the $\mathrm{TiO}_{2} / \mathrm{CeO}_{x}$ film exhibits a reduced root-mean-square (RMS) surface roughness (RMS $=19.2 \mathrm{~nm})$ compared with that of the $\mathrm{TiO}_{2}$ film $(\mathrm{RMS}=$ $16.1 \mathrm{~nm}$ ), which is in good agreement with the SEM results.

To investigate the influence of the $\mathrm{CeO}_{x}$ interlayer on the morphology and crystallinity properties of perovskite films, SEM and XRD were conducted on the perovskite films deposited onto $\mathrm{TiO}_{2}$ and $\mathrm{TiO}_{2} / \mathrm{CeO}_{x}$ ETLs. As shown in Fig. 2a-d, the grain sizes and film thicknesses of
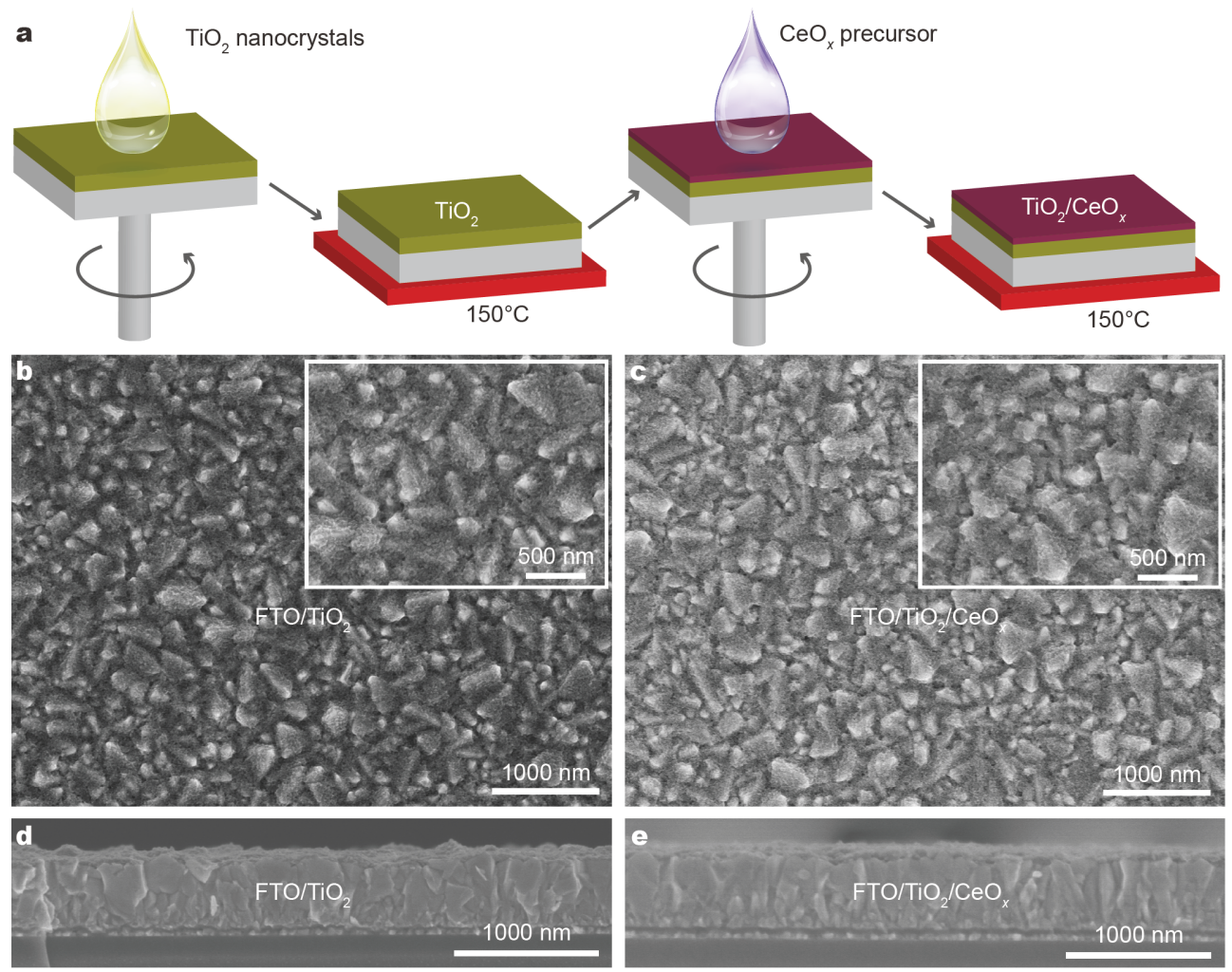

Figure 1 (a) Preparation of the low-temperature solution-processed $\mathrm{TiO}_{2}$ and $\mathrm{TiO}_{2} / \mathrm{CeO}_{x}$ films. (b, c) Surface $\mathrm{SEM}$ images of the $\mathrm{TiO}_{2}$ and $\mathrm{TiO}_{2} /$ $\mathrm{CeO}_{x}$ films. The insets show the corresponding high-magnification SEM images. (d, e) Cross-sectional SEM images of the $\mathrm{TiO}_{2}$ and $\mathrm{TiO}_{2} / \mathrm{CeO}_{x}$ films. 
the perovskite films deposited onto $\mathrm{TiO}_{2}$ and $\mathrm{TiO}_{2} / \mathrm{CeO}_{x}$ ETLs are similar. The perovskite film based on $\mathrm{TiO}_{2} / \mathrm{CeO}_{x}$ ETL exhibits a slightly enhanced absorption compared with the perovskite film based on the $\mathrm{TiO}_{2}$ ETL (Fig. 2e). Fig. $2 \mathrm{f}$ shows the XRD patterns of the perovskite films deposited onto the $\mathrm{TiO}_{2}$ and $\mathrm{TiO}_{2} / \mathrm{CeO}_{x}$ ETLs. The main peaks located at $14.1^{\circ}$ and $28.5^{\circ}$ correspond to the (110) and (220) crystal planes of the cubic perovskite phase, respectively [29]. The perovskite (110) peak intensity does not show any discernible difference between the two films. Analogously, the full-width-at-half-maximum values of this perovskite (110) peak are similar for the two films ( 0.12 for the $\mathrm{TiO}_{2}$-based film and 0.11 for the $\mathrm{TiO}_{2} /$ $\mathrm{CeO}_{x}$-based film). In addition, the ratio of the perovskite (110) peak intensity to the perovskite (220) peak intensity is 1.91 and 1.93 for the films deposited onto the $\mathrm{TiO}_{2}$ and $\mathrm{TiO}_{2} / \mathrm{CeO}_{x}$ ETLs, respectively. These results suggest that the introduction of the $\mathrm{CeO}_{x}$ interlayer has no significant effect on the morphologies and crystalline properties of the perovskite films.

XPS measurements were performed to confirm the presence of $\mathrm{CeO}_{x}$ interlayer and investigate its chemical composition. Fig. 3a shows the XPS survey for the $\mathrm{TiO}_{2}$ and $\mathrm{TiO}_{2} / \mathrm{CeO}_{x}$ films, whereas Fig. $3 \mathrm{~b}$ illustrates the highresolution Ce $3 \mathrm{~d}$ core level spectra. An evident Ce $3 \mathrm{~d}$ peak can be observed in the $\mathrm{TiO}_{2} / \mathrm{CeO}_{x}$ film, whereas such a peak is absent in the spectra of the $\mathrm{TiO}_{2}$ film. Fig. S4 shows the deconvolution of the Ce $3 \mathrm{~d}$ core level XPS spectra for the $\mathrm{TiO}_{2} / \mathrm{CeO}_{x}$ film. Both $\mathrm{Ce}^{3+}$ and $\mathrm{Ce}^{4+}$ emissions are present in the obtained $\mathrm{CeO}_{x}$ film. Regarding the spectrum of the fully oxidized $\mathrm{CeO}_{2}$ film, six peaks can be identified, which correspond to three pairs of spin-orbit split doublets [30]. These peaks are labeled using conventional notations $\left(\mathrm{U}, \mathrm{U}^{\prime \prime}, \mathrm{U}^{\prime \prime}, \mathrm{V}, \mathrm{V}^{\prime \prime}\right.$, and $\left.V^{\prime \prime \prime}\right)$. $U$ and $V$ refer to the $3 d_{3 / 2}$ and $3 d_{5 / 2}$ levels, respectively. The peaks labeled as $\mathrm{U} / \mathrm{V}, \mathrm{U}^{\prime \prime} / \mathrm{V}^{\prime \prime}$, and $\mathrm{U}^{\prime \prime \prime} / \mathrm{V}^{\prime \prime \prime}$ are assigned to a mixture of Ce $3 d^{9} 4 f^{2} \mathrm{O} 2 \mathrm{p}^{4}$, Ce $3 \mathrm{~d}^{9} 4 \mathrm{f}^{1} \mathrm{O} 2 \mathrm{p}^{5}$, and Ce $3 d^{9} 4 f^{0} O 2 p^{6}$, respectively. For the reduced ceria films, the spectra show two more pairs of doublets (indicated as $U_{0}, U^{\prime}, V_{0}$, and $V^{\prime}$ ), which originated from different $\mathrm{Ce} 4 \mathrm{f}$ configurations in the initial and final states associated with the $\mathrm{Ce}^{3+}$ ions. The peaks labeled as $\mathrm{U}_{0} / \mathrm{V}_{0}$ and $\mathrm{U}^{\prime} / \mathrm{V}^{\prime}$ are assigned to a mixture of Ce $3 \mathrm{~d}^{9} 4 \mathrm{f}^{2} \mathrm{O} 2 \mathrm{p}^{5}$ and Ce $3 \mathrm{~d}^{9} 4 \mathrm{f}^{1} \mathrm{O} 2 \mathrm{p}^{6}$, respectively. Therefore, the Ce $3 \mathrm{~d}$ XPS region contains 10 peaks originating from different Ce oxidation states $\left(\mathrm{Ce}^{3+}\right.$ and $\left.\mathrm{Ce}^{4+}\right)$ and their $4 \mathrm{f}$ configurations. The component labeled $\mathrm{U}^{\prime \prime \prime} / \mathrm{V}^{\prime \prime \prime}$ is indicative of the Ce $3 \mathrm{~d}^{9} 4 \mathrm{f}^{0} \mathrm{O} 2 \mathrm{p}^{6}$ final state, which is associated with the presence of $\mathrm{Ce}^{4+}$ ions. The $\mathrm{Ce}^{3+}$ concentration in the Ce $3 \mathrm{~d}$ spectrum is determined to be 0.46 ; therefore, the value of $x$ in the as-prepared $\mathrm{CeO}_{x}$ is 1.77 , which is in good agreement with previous studies [28,31]. It is worth noting that the presence of the $\mathrm{TiO}_{2}$ support contributes to the increase in the $\mathrm{Ce}^{3+}$ concentration via interface stabilization [32-34]. Energy-dispersive spectroscopy mapping confirmed the uniform coverage of $\mathrm{CeO}_{x}$ on top of the $\mathrm{TiO}_{2}$ film (Fig. S5). Due to the presence of the oxygen-deficient $\mathrm{CeO}_{x}$ layer, it can be inferred that charge
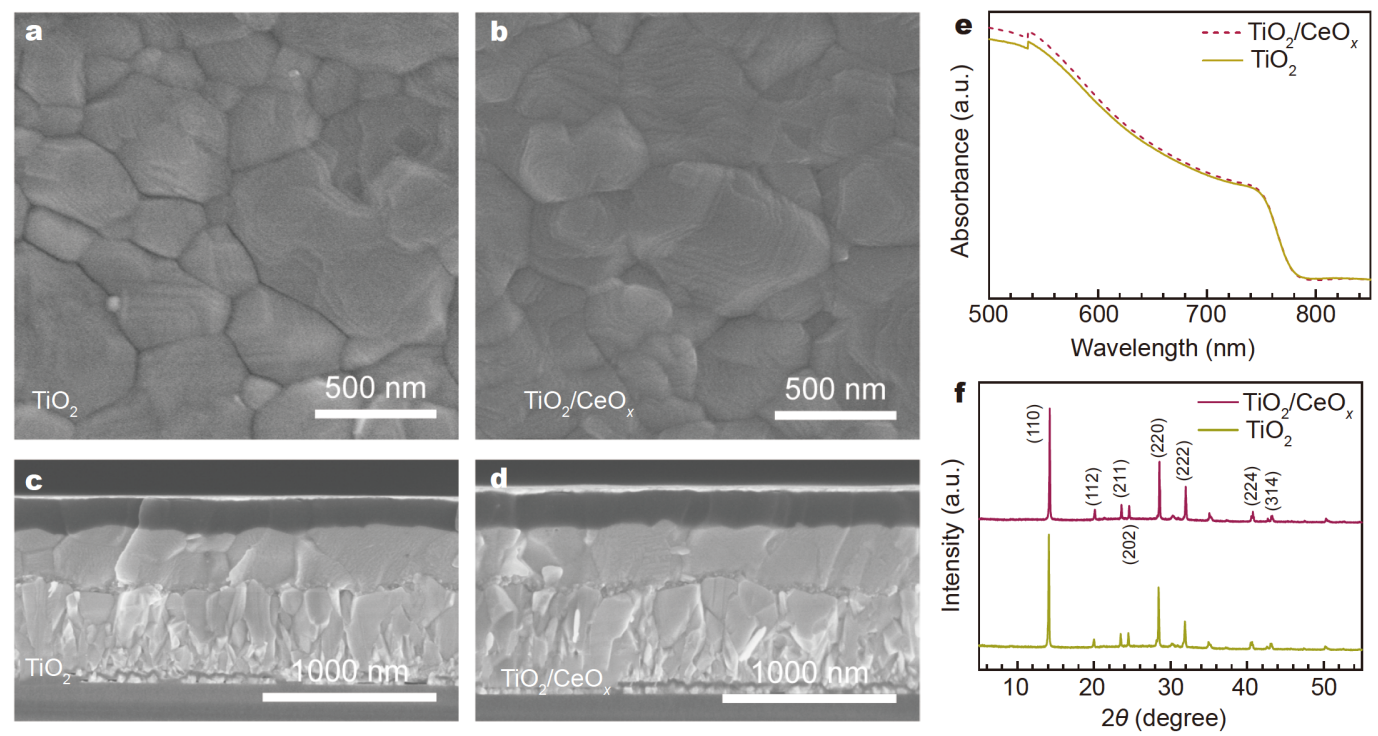

Figure 2 (a, b) Top-view SEM images of the perovskite films deposited onto the $\mathrm{TiO}_{2}$ and $\mathrm{TiO}_{2} / \mathrm{CeO}_{x}$ ETLs. (c, d) Cross-sectional view of the PSCs based on the $\mathrm{TiO}_{2}$ and $\mathrm{TiO}_{2} / \mathrm{CeO}_{x}$ ETLs. (e) UV-Vis absorption spectra of the perovskite films deposited onto the $\mathrm{TiO}_{2}$ and $\mathrm{TiO}_{2} / \mathrm{CeO} \mathrm{ETLs}$ (f) XRD patterns of the perovskite films deposited onto the $\mathrm{TiO}_{2}$ and $\mathrm{TiO}_{2} / \mathrm{CeO}_{x}$ ETLs. 

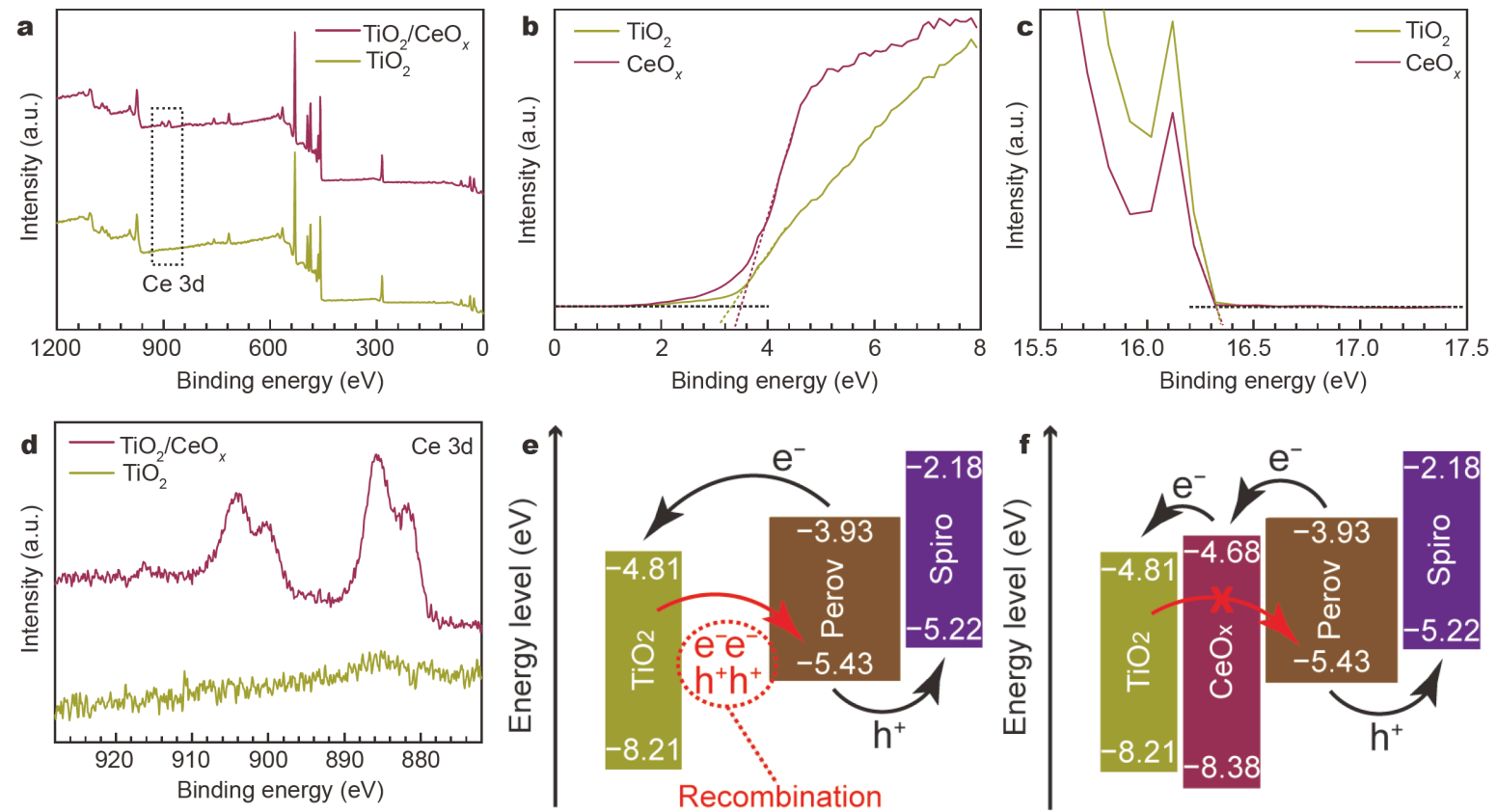

Figure 3 (a) XPS survey of the $\mathrm{TiO}_{2}$ and $\mathrm{TiO}_{2} / \mathrm{CeO}_{x}$ films. (b) Ce $3 \mathrm{~d}$ core level spectra of the $\mathrm{TiO}_{2}$ and $\mathrm{TiO}_{2} / \mathrm{CeO}$ films. (c, d) Valence band spectra and secondary electron cut-off for the $\mathrm{TiO}_{2}$ and $\mathrm{CeO}_{x}$ films. (e, f) Schematics of band alignment for the PSCs based on the TiO${ }_{2}$ and $\mathrm{TiO}_{2} / \mathrm{CeO} \mathrm{ETLs}$.

recombination may occur at the $\mathrm{CeO}_{x} /$ perovskite interface. With this in mind, UV-ozone treatment was applied to remove surface oxygen vacancies and thus alleviate interface recombination [35,36].

Energy level matching between the perovskite layer and ETLs is critical for achieving high-performance PSCs. UPS measurements were performed to determine the energy level positions of the $\mathrm{TiO}_{2}$ and $\mathrm{CeO}_{x}$ films. Fig. 3c, $\mathrm{d}$ show the valence band spectra and secondary electron cut-off for the $\mathrm{TiO}_{2}$ and $\mathrm{CeO}_{\mathrm{x}}$ films. According to the valence band spectra, the energy difference between the valence band maximum (VBM) and Fermi level was found to be $\sim 3.33$ and $\sim 3.50 \mathrm{eV}$ for the $\mathrm{TiO}_{2}$ and $\mathrm{CeO}_{x}$ films, respectively. Additionally, the secondary electron cut-off is $\sim 16.32 \mathrm{eV}$ for both $\mathrm{TiO}_{2}$ and $\mathrm{CeO}_{x}$ films, corresponding to a work function of $4.88 \mathrm{eV}$. Therefore, the VBMs for the $\mathrm{TiO}_{2}$ and $\mathrm{CeO}_{x}$ films were estimated to be -8.21 and $-8.38 \mathrm{eV}$, respectively. By combining VBM positions with optical bandgaps [27,31], the conduction band minimums (CBMs) were determined to be -4.81 and $-4.68 \mathrm{eV}$ for the $\mathrm{TiO}_{2}$ and $\mathrm{CeO}_{x}$ films, respectively. Based on these values and reported band edges of $\mathrm{MAPbI}_{3}$ and Spiro-OMeTAD [37], the energy band diagrams for the PSCs employing $\mathrm{TiO}_{2}$ and $\mathrm{TiO}_{2} / \mathrm{CeO}_{x}$ as ETLs were derived, as illustrated in Fig. 3e, f. Because the $\mathrm{CBM}$ of $\mathrm{CeO}_{x}$ lies between those of $\mathrm{MAPbI}_{3}$ and $\mathrm{TiO}_{2}$, photogenerated electrons in the conduction band of
$\mathrm{MAPbI}_{3}$ can cascade into $\mathrm{TiO}_{2}$ via $\mathrm{CeO}_{x}$. This optimally positioned band alignment facilitates the extraction of electrons from the perovskite and their subsequent injection into $\mathrm{TiO}_{2}$. Additionally, $\mathrm{CeO}_{x}$ functions as a holeblocking layer to suppress the electrons' back transfer from $\mathrm{TiO}_{2}$ to the perovskite. The energy barrier at the $\mathrm{TiO}_{2} / \mathrm{CeO}_{x}$ interface can effectively block charge recombination, which should essentially increase the quasiFermi level for electrons and raise the $V_{\text {oc }}$ value.

To assess the influence of the $\mathrm{CeO}_{x}$ interlayer on the photovoltaic performance of PSCs, devices with the structure of $\mathrm{FTO} / \mathrm{ETLs} / \mathrm{MAPbI}_{3} / \mathrm{Spiro}_{\mathrm{OM}} \mathrm{OMAD} / \mathrm{Au}$ were assembled, as schematically illustrated in Fig. 4a. Fig. $4 \mathrm{~b}$ shows the $J-V$ curves (under reverse scan) for the PSCs based on the $\mathrm{TiO}_{2}$ and $\mathrm{TiO}_{2} / \mathrm{CeO}_{x}$ ETLs with the photovoltaic parameters summarized in Table 1. The $\mathrm{TiO}_{2}$-based device exhibits a PCE of $18.61 \%$, with a shortcircuit current density $\left(J_{\text {sc }}\right)$ of $23.18 \mathrm{~mA} \mathrm{~cm}{ }^{-2}, V_{\text {oc }}$ of $1.08 \mathrm{~V}$, and $\mathrm{FF}$ of $74.64 \%$. Upon introducing the $\mathrm{CeO}_{x}$ interlayer, no obvious change is observed in the $J_{\mathrm{sc}}$ value $\left(23.14 \mathrm{~mA} \mathrm{~cm}^{-2}\right)$; however, $V_{\text {oc }}$ and $\mathrm{FF}$ increase to $1.13 \mathrm{~V}$ and $76.39 \%$, respectively, yielding a promising PCE of more than $20 \%$. Fig. $4 \mathrm{c}$ presents a statistical comparison of the averaged PCE from 36 individual devices with the $\mathrm{TiO}_{2}$ and $\mathrm{TiO}_{2} / \mathrm{CeO}_{x}$ ETLs. Compared with the $\mathrm{TiO}_{2}-$ based devices $(17.27 \% \pm 0.65 \%)$, the $\mathrm{TiO}_{2} / \mathrm{CeO}_{x}$ devices exhibit an improvement in the averaged PCE $(19.17 \% \pm$ 
a
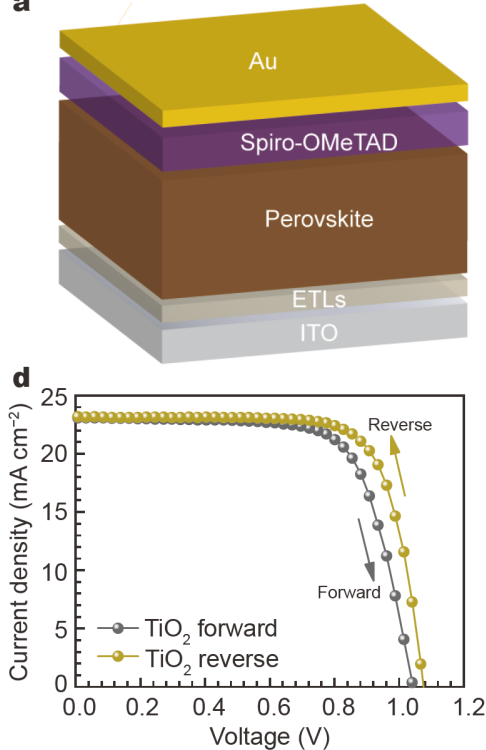
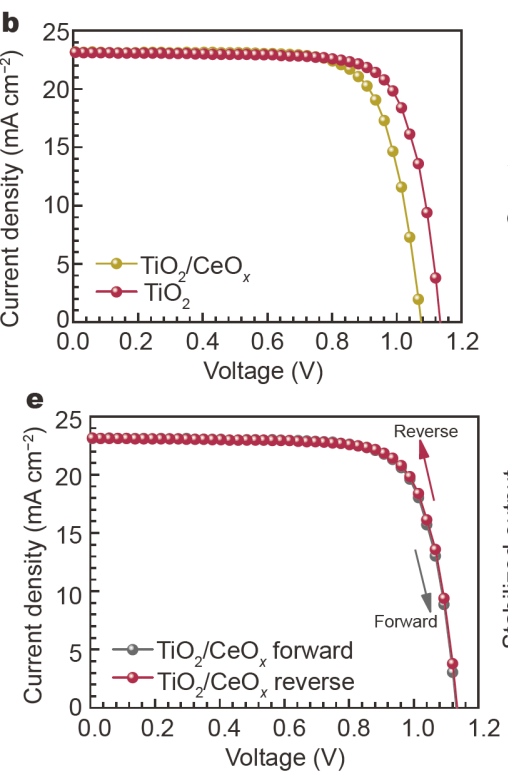

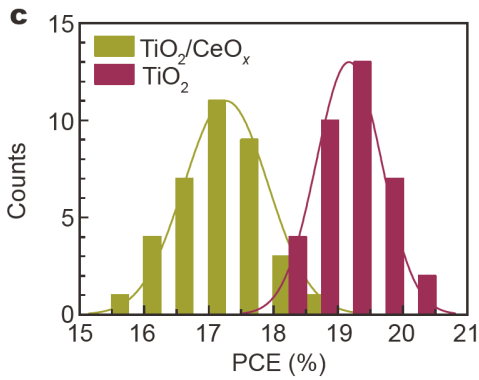

$\mathbf{f}$

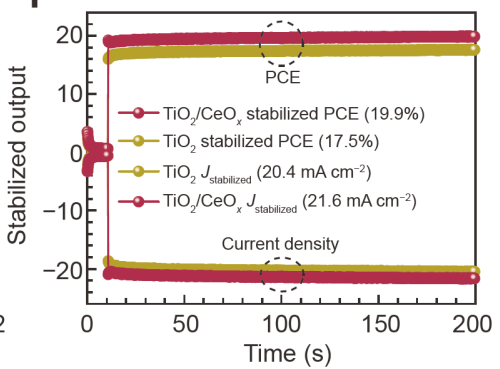

Figure 4 (a) Device configuration. (b) $J-V$ curves of the PSCs based on the $\mathrm{TiO}_{2}$ and $\mathrm{TiO}_{2} / \mathrm{CeO}{ }_{x}$ ETLs. (c) PCE distributions of the PSCs based on the $\mathrm{TiO}_{2}$ and $\mathrm{TiO}_{2} / \mathrm{CeO}_{x}$ ETLs. (d) $J-V$ curves of the PSC based on the $\mathrm{TiO}_{2}$ ETL under both reverse- and forward-scan directions. (e) $J-V$ curves of the PSC based on the $\mathrm{TiO}_{2} / \mathrm{CeO}_{x}$ ETL under both reverse- and forward-scan directions. (f) Steady-state power output of the PSCs based on the TiO 2 and $\mathrm{TiO}_{2} / \mathrm{CeO}_{x}$ ETLs.

Table 1 Photovoltaic parameters of the PSCs based on the $\mathrm{TiO}_{2}$ and $\mathrm{TiO}_{2} / \mathrm{CeO}_{x}$ ETLs

\begin{tabular}{ccccccc}
\hline Devices & $\begin{array}{c}\text { Scan direc- } \\
\text { tion }\end{array}$ & $\begin{array}{c}J_{\mathrm{sc}} \\
\left(\mathrm{mA} \mathrm{cm}^{-2}\right)\end{array}$ & $\begin{array}{c}V_{\mathrm{oc}} \\
(\mathrm{V})\end{array}$ & $\begin{array}{c}\mathrm{FF} \\
(\%)\end{array}$ & $\begin{array}{c}\text { PCE } \\
(\%)\end{array}$ & $\begin{array}{c}\mathrm{HI} \\
(\%)\end{array}$ \\
\hline \multirow{2}{*}{$\mathrm{TiO}_{2}$} & Reverse & 23.18 & 1.08 & 74.64 & 18.61 & \\
& Forward & 23.08 & 1.04 & 70.91 & 17.07 & 9.0 \\
& Reverse & 23.14 & 1.13 & 76.39 & 20.05 & \multirow{2}{*}{$\mathrm{TiO}_{2} / \mathrm{CeO}_{x}$} \\
& Forward & 23.15 & 1.13 & 76.09 & 19.94 & 0.6 \\
\hline
\end{tabular}

$0.50 \%)$ with a narrower PCE distribution. This further confirms the enhanced photovoltaic performance and reproducibility that can be obtained with the introduction of the $\mathrm{CeO}_{x}$ interlayer.

Fig. $4 \mathrm{~d}$, e show the $J-V$ curves measured under both reverse and forward scans. The corresponding photovoltaic parameters are listed in Table 1 . It was found that the $\mathrm{TiO}_{2} / \mathrm{CeO}_{x}$-based device shows negligible hysteresis, whereas the pure $\mathrm{TiO}_{2}$-based device exhibits large hysteresis. To quantify the variation in the hysteresis behavior, the hysteresis index (HI) was calculated [37]. The HI decreased from $9.0 \%\left(\mathrm{TiO}_{2}\right.$-based device) to $0.6 \%\left(\mathrm{TiO}_{2} /\right.$ $\mathrm{CeO}_{x}$-based device), which can be ascribed to the improved electron extraction. Steady-state power output under continuous illumination can provide a more accurate and reliable photovoltaic performance for the devices under working conditions. Fig. $4 \mathrm{f}$ shows the steady- state PCE and current density measured at maximum power point. The PCEs for the PSCs based on $\mathrm{TiO}_{2}$ and $\mathrm{TiO}_{2} / \mathrm{CeO}_{x}$ ETLs stabilize at $17.5 \%$ and $19.9 \%$ with photocurrent densities of 20.4 and $21.6 \mathrm{~mA} \mathrm{~cm}{ }^{-2}$, respectively. It should be noted that these values are very close to those obtained from the $J-V$ measurements.

Compared with the PSCs using $\mathrm{TiO}_{2}$ as the ETL, a higher $V_{\text {oc }}$ value is obtained when $\mathrm{TiO}_{2} / \mathrm{CeO}_{x}$ is used as the ETL. When a solar cell is under illumination, the $V_{\text {oc }}$ is related to the splitting of quasi-Fermi levels for electrons and holes. These quasi-Fermi level positions are set by the free-carrier concentration, which in turn is determined by the equilibrium between carrier generation and recombination rates [38,39]. For PSCs based on different ETLs, the carrier generation process is identical, and the enhanced $V_{\text {oc }}$ observed in the $\mathrm{TiO}_{2} / \mathrm{CeO}_{x}$-based devices indicates a suppressed recombination of carriers either in the perovskite bulk or at the ETLs/perovskite interface. Considering the similar qualities of the perovskite films deposited onto $\mathrm{TiO}_{2}$ and $\mathrm{TiO}_{2} / \mathrm{CeO}_{x}$ ETLs (see Fig. 2), the enhancement of $V_{\text {oc }}$ can be ascribed to the suppressed interfacial carrier recombination obtained due to the addition of the $\mathrm{CeO}_{x}$ interlayer. To understand the carrier recombination process in the PSCs, the $J-V$ characteristics were analyzed based on the equivalent circuit model. Generally, the $J-V$ characteristics of a semiconductor junction can be described as follows 
$[37,40]:$

$$
-\frac{\mathrm{d} V}{\mathrm{~d} J}=\frac{m k_{\mathrm{B}} T}{q}\left(J_{\mathrm{sc}}-J\right)^{-1}+R_{\mathrm{s}}
$$

where $m$ is the ideality factor, $k_{\mathrm{B}}$ is the Boltzmann constant, $T$ is the temperature, $q$ is the electron charge, $J_{\mathrm{sc}}$ is the photo-induced current density, and $R_{\mathrm{s}}$ is the series resistance. The value of $m$ can be obtained by fitting the linear part of the $-\mathrm{d} V / \mathrm{d} J v s$. $\left(J_{\mathrm{sc}}-J\right)^{-1}$ curves, as shown in Fig. 5a. The $\mathrm{TiO}_{2} / \mathrm{CeO}_{x}$-based device exhibits a decreased $m$ value (2.23) compared with the $\mathrm{TiO}_{2}$-based device (2.62). Generally, lower $m$ value indicates a smaller probability for charge carrier recombination in PSCs [41]. Therefore, the reduced $m$ value suggests a suppressed nonradiative carrier recombination in the $\mathrm{TiO}_{2} / \mathrm{CeO}_{x^{-}}$ based PSCs.

To further elucidate the improved optoelectronic quality and understand the carrier recombination process in PSCs with different ETLs, light intensity $(\varphi)$-dependent $V_{\text {oc }}$ characteristics were measured, as shown in Fig. 5b [3]. The relationship between $V_{\text {oc }}$ and $\varphi$ can be described as $V_{\text {oc }}=\alpha\left(k_{\mathrm{B}} T / q\right) \ln \varphi$, where $\alpha$ is a constant [42]. Assuming a homogeneous carrier profile in the PSCs, for a trap-free bimolecular recombination, $\alpha$ should be close to 1 . On the contrary, if trap-assisted monomolecular recombination (mainly Shockley-Read-Hall recombination) dominates, $\alpha$ approaches 2. Thus, the deviation of $\alpha$ from 1 indicates the occurrence of nonradiative trap-assisted carrier recombination in the PSCs. The control device without the $\mathrm{CeO}_{x}$ interlayer exhibited a slope of $1.71 k_{\mathrm{B}} T / q$, suggesting a severe nonradiative loss due to trap-assisted recombination. A slope of $1.46 k_{\mathrm{B}} T / q$ was achieved when the $\mathrm{TiO}_{2}$ /perovskite interface was modified with the addition of $\mathrm{CeO}_{x}$. This proves the role of $\mathrm{CeO}_{x}$ in reducing the interfacial nonradiative recombination in PSCs. $V_{\text {oc }}$ decay measurements were conducted to investigate the transient process of carrier recombination in PSCs. Fig. 5c illustrates the $V_{\text {oc }}$ decay curves of the PSCs with or without the $\mathrm{CeO}_{x}$ interlayer. It can be seen that the PSCs with the $\mathrm{CeO}_{x}$ interlayer exhibited a slower decay rate and longer decay time than the cells without the $\mathrm{CeO}_{x}$ interlayer. The $V_{\text {oc }}$ decay time constant for the $\mathrm{TiO}_{2} / \mathrm{CeO}_{x}$-based device $(2.16 \mathrm{~ms})$ was estimated to be twice as large as that for the $\mathrm{TiO}_{2}$-based device $(1.03 \mathrm{~ms})$. This result suggests that the PSCs that use the $\mathrm{CeO}_{x}$ interlayer possess a much longer carrier lifetime and lower interface recombination rate than the cells without the $\mathrm{CeO}_{x}$ interlayer; this is in consistent with the observed high $V_{\text {oc }}$ and FF values of the devices with $\mathrm{CeO}_{x}$. The electron lifetime $\left(\tau_{\mathrm{n}}\right)$ can be derived from Fig. $5 c$ on the basis of the following equation [43]:

$\tau_{\mathrm{n}}=-\frac{k_{\mathrm{B}} T}{q}\left(\frac{\mathrm{d} V_{\mathrm{oc}}}{\mathrm{d} t}\right)^{-1}$
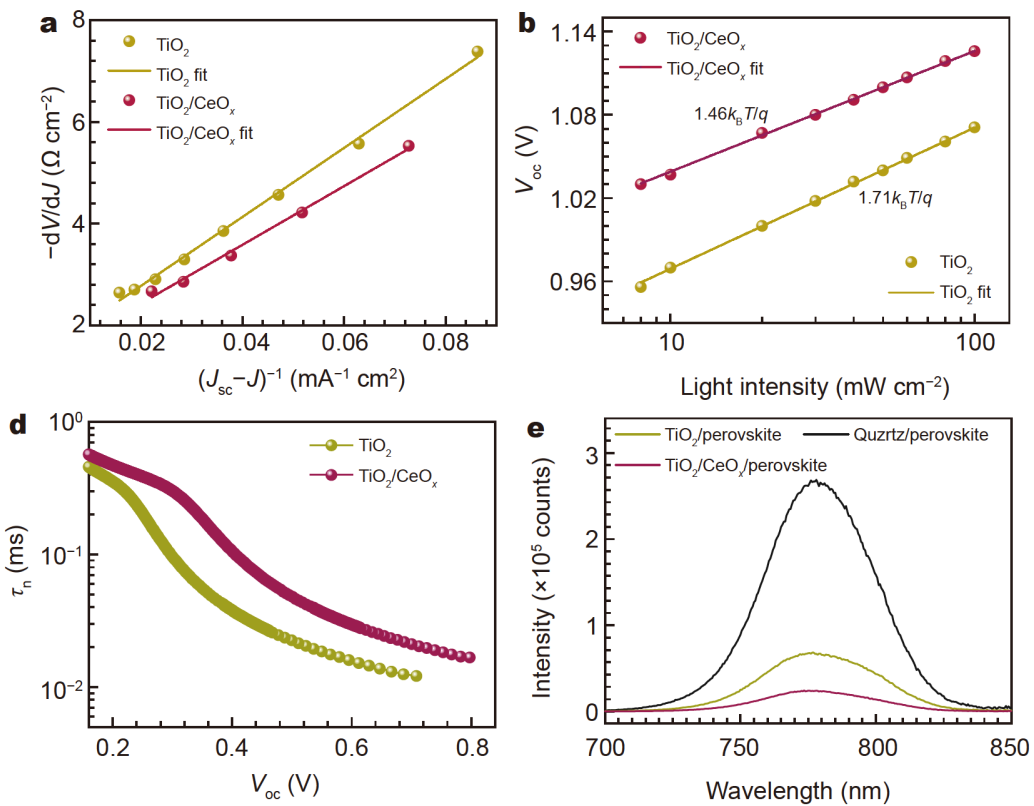
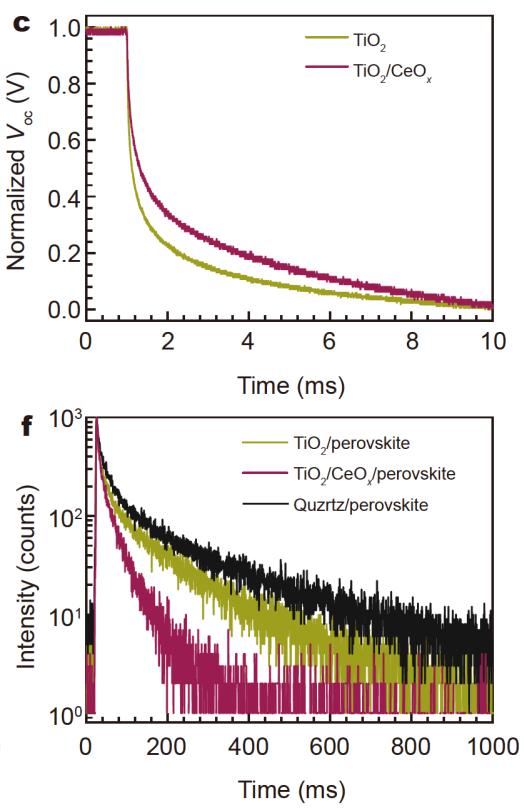

Figure 5 (a) Plots of $-\mathrm{d} V / \mathrm{d} J$ vs. $\left(J_{\text {sc }}-J\right)^{-1}$ for the PSCs based on the $\mathrm{TiO}_{2}$ and $\mathrm{TiO}_{2} / \mathrm{CeO}_{x}$ ETLs and corresponding linear fittings. (b) $V_{\text {oc }} v s$. light intensity for the PSCs based on the $\mathrm{TiO}_{2}$ and $\mathrm{TiO}_{2} / \mathrm{CeO}_{x}$ ETLs and corresponding linear fittings. (c) $V_{\text {oc }}$ decay curves for the PSCs based on the TiO and $\mathrm{TiO}_{2} / \mathrm{CeO}_{x}$ ETLs. (d) Calculated electron lifetimes for the PSCs based on the $\mathrm{TiO}_{2}$ and $\mathrm{TiO}_{2} / \mathrm{CeO}_{x}$ ETLs. (e, f) Steady-state PL spectra and TRPL decays of the perovskite films depositied onto quartz, $\mathrm{TiO}_{2}$, and $\mathrm{TiO}_{2} / \mathrm{CeO}_{x}$ substrates. 
The dependence of $\tau_{\mathrm{n}}$ on $V_{\mathrm{oc}}$ is shown in Fig. 5d; it can be seen that the $\mathrm{TiO}_{2} / \mathrm{CeO}_{x}$-based device exhibits longer $\tau_{\mathrm{n}}$ than the $\mathrm{TiO}_{2}$-based cell.

Steady-state PL measurements were conducted to study the charge transfer process between the perovskite and ETLs. Fig. 5e shows the PL spectra of perovskite films deposited onto different ETLs. A more strongly quenched PL was observed for the perovskite films based on the $\mathrm{TiO}_{2} / \mathrm{CeO}_{x}$ ETL. This result suggests that electron extraction from the perovskite is more efficient for the $\mathrm{TiO}_{2} / \mathrm{CeO}_{x}$ ETL; this is consistent with the improved energy level matching between the perovskite and the $\mathrm{TiO}_{2} / \mathrm{CeO}_{x}$ ETL. Time-resolved PL (TRPL) measurements were performed to explore the dynamic recombination behavior of perovskite films prepared on different ETLs, as shown in Fig. 5f and Table S1. The TRPL decay curves were fitted using the biexponential equation, $I(t)=I_{0}+A_{1} \exp \left(-t / \tau_{1}\right)+A_{2} \exp \left(-t / \tau_{2}\right)$, where $\tau_{1}$ and $\tau_{2}$ represent the fast and slow decay time constants, respectively. In general, $\tau_{1}$ and $\tau_{2}$ are associated with the quenching of charge carriers by electron extraction from the perovskite to ETLs and nonradiative recombination in the perovskite bulk, respectively [37]. The $\mathrm{TiO}_{2}$ ETLloaded perovskite exhibited a PL decay time of $\tau_{1}=$ $15.1 \mathrm{~ns}$ and $\tau_{2}=139.9 \mathrm{~ns}$, which are obviously slower than that of pure perovskite (Table S1). For the $\mathrm{TiO}_{2} / \mathrm{CeO}_{x}$ ETL-loaded perovskite, both $\tau_{1}$ and $\tau_{2}$ decreased to 6.1 and $39.7 \mathrm{~ns}$, respectively, suggesting an enhanced electron extraction between the perovskite and the $\mathrm{TiO}_{2} / \mathrm{CeO}_{x}$ ETL. This is also confirmed by the reduced average lifetime from 107.8 to $31.0 \mathrm{~ns}$. The enhanced electron extraction might originate from the improved band alignment and suppressed interfacial recombination obtained with the $\mathrm{CeO}_{x}$ layer insertion.

As previously reported, PSCs based on $\mathrm{TiO}_{2}$ ETLs suffer light-induced degradation due to the photocatalytic activity of $\mathrm{TiO}_{2}[26,44]$. Fig. 6 shows the normalized PCE decay of PSCs based on the $\mathrm{TiO}_{2}$ and $\mathrm{TiO}_{2} / \mathrm{CeO}_{x}$ ETLs as a function of storage time under 1 sun illumination. The PSCs based on the $\mathrm{TiO}_{2} / \mathrm{CeO}_{x}$ ETL exhibited an outstanding light stability, maintaining over $88 \%$ initial PCE value after being aged for $300 \mathrm{~min}$. By contrast, the PSCs based on the $\mathrm{TiO}_{2}$ ETL almost failed after being aged for the same duration [28]. We speculate that the enhanced light stability is a result of two aspects. On the one hand, the presence of the $\mathrm{CeO}_{x}$ interlayer prevents the $\mathrm{TiO}_{2}$ layer from directly contacting the perovskite layer, reducing the problem of photodegradation. On the other hand, the weakening of the device interface recombination contributes to the improvement of stability. It is

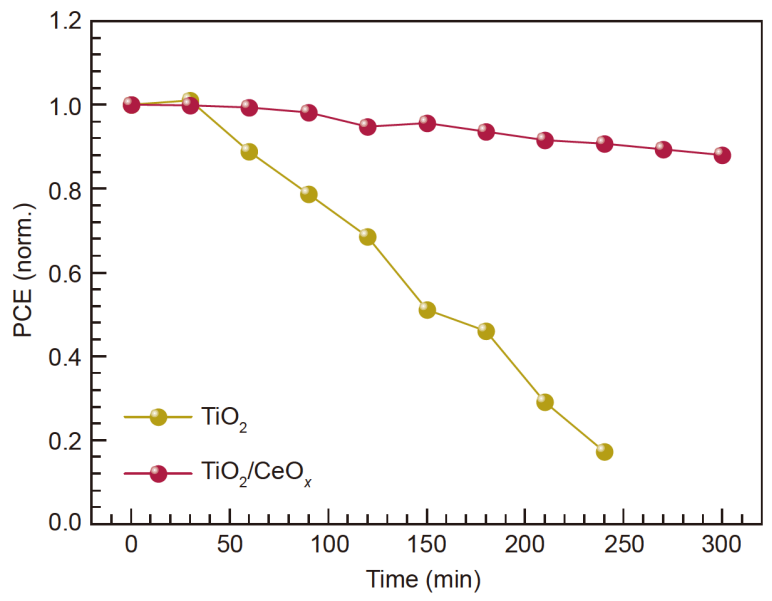

Figure 6 Normalized PCE decay of the unencapsulated PSCs based on the $\mathrm{TiO}_{2}$ and $\mathrm{TiO}_{2} / \mathrm{CeO}_{x}$ ETLs as a function of the storage time under $100 \mathrm{~mW} \mathrm{~cm}^{-2}$ irradiation (ambient air).

important to note that a defective (oxygen-deficient) $\mathrm{TiO}_{2}$ ETL was reported to improve the PCE and stability of PSCs owing to an unexpectedly large photoconductive gain and reduced ultraviolet photocatalytic activity [45]. Therefore, the effect of oxygen vacancy on device stability cannot be ruled out.

\section{CONCLUSIONS}

In summary, we demonstrated that the interfacial recombination losses of PSCs based on low-temperatureprocessed $\mathrm{TiO}_{2}$ can be significantly reduced with introduction of $\mathrm{a} \mathrm{CeO}_{x}$ interlayer. The introduction of $\mathrm{CeO}_{x}$ creates a cascade pathway for electron transport so that photogenerated electrons in the conduction band of $\mathrm{MAPbI}_{3}$ can cascade into $\mathrm{TiO}_{2}$ via $\mathrm{CeO}_{x}$. This optimally positioned band alignment facilitates the extraction of electrons from the perovskite and their subsequent injection into $\mathrm{TiO}_{2}$. Moreover, $\mathrm{CeO}_{x}$ suppresses the electrons' back transfer from $\mathrm{TiO}_{2}$ to the perovskite due to the energy barrier at the $\mathrm{TiO}_{2} / \mathrm{CeO}_{x}$ interface. This can effectively block interfacial charge recombination, leading to an increase in the quasi-Fermi level for electrons and an enhancement of the $V_{\text {oc }}$. As a result, the $\mathrm{TiO}_{2} / \mathrm{CeO}_{x^{-}}$ based device exhibits a maximum $V_{\text {oc }}$ of $1.13 \mathrm{~V}$ with 300$\mathrm{mV}$ potential loss compared with the $\mathrm{TiO}_{2}$-based control device $(1.08 \mathrm{~V}$ and $520 \mathrm{mV})$. The enhancement of $V_{\mathrm{oc}}$, together with the increase in FF (from $~ 74 \%$ to $~ 76 \%$ ), enables a PCE improvement from $\sim 18 \%$ to more than $20 \%$. These results suggest that designing an adequate band alignment is an effective way to reduce interfacial charge recombination and further improve the device 


\section{performance of PSCs.}

\section{Received 12 November 2020; accepted 22 January 2021; published online 2 April 2021}

1 Kim JY, Lee JW, Jung HS, et al. High-efficiency perovskite solar cells. Chem Rev, 2020, 120: 7867-7918

2 Jena AK, Kulkarni A, Miyasaka T. Halide perovskite photovoltaics: Background, status, and future prospects. Chem Rev, 2019, 119: 3036-3103

3 Shi X, Chen J, Wu Y, et al. Efficient formamidinium-based planar perovskite solar cells fabricated through a $\mathrm{CaI}_{2}-\mathrm{PbI}_{2}$ precursor. ACS Sustain Chem Eng, 2020, 8: 4267-4275

4 Ma S, Cai M, Cheng T, et al. Two-dimensional organic-inorganic hybrid perovskite: From material properties to device applications. Sci China Mater, 2018, 61: 1257-1277

5 Shi P, Ding Y, Liu C, et al. Advanced partial nucleation for singlephase $\mathrm{FA}_{0.92} \mathrm{MA}_{0.08} \mathrm{PbI}_{3}$-based high-efficiency perovskite solar cells. Sci China Mater, 2019, 62: 1846-1856

6 Https://www.Nrel.Gov/pv/assets/pdfs/best-research-cell-efficiencies.20200925.Pdf

7 Tress W. Perovskite solar cells on the way to their radiative efficiency limit-insights into a success story of high open-circuit voltage and low recombination. Adv Energy Mater, 2017, 7: 1602358

8 Stolterfoht M, Wolff CM, Márquez JA, et al. Visualization and suppression of interfacial recombination for high-efficiency largearea pin perovskite solar cells. Nat Energy, 2018, 3: 847-854

9 Stolterfoht M, Caprioglio P, Wolff CM, et al. The impact of energy alignment and interfacial recombination on the internal and external open-circuit voltage of perovskite solar cells. Energy Environ Sci, 2019, 12: 2778-2788

10 Wolff CM, Caprioglio P, Stolterfoht M, et al. Nonradiative recombination in perovskite solar cells: The role of interfaces. Adv Mater, 2019, 31: 1902762

11 Rajagopal A, Yao K, Jen AKY. Toward perovskite solar cell commercialization: A perspective and research roadmap based on interfacial engineering. Adv Mater, 2018, 30: 1800455

12 Shi $\mathrm{X}$, Chen $\mathrm{R}$, Jiang $\mathrm{T}$, et al. Regulation of interfacial charge transfer and recombination for efficient planar perovskite solar cells. Sol RRL, 2020, 4: 1900198

13 Chen J, Park NG. Materials and methods for interface engineering toward stable and efficient perovskite solar cells. ACS Energy Lett, 2020, 5: 2742-2786

14 Choi $\mathrm{K}$, Choi $\mathrm{H}$, Min J, et al. A short review on interface engineering of perovskite solar cells: A self-assembled monolayer and its roles. Sol RRL, 2020, 4: 1900251

15 Qiu J, Yang S. Material and interface engineering for high-performance perovskite solar cells: A personal journey and perspective. Chem Rec, 2020, 20: 209-229

16 Mingorance $\mathrm{A}$, Xie $\mathrm{H}$, Kim $\mathrm{H}-$, et al. Interfacial engineering of metal oxides for highly stable halide perovskite solar cells. Adv Mater Interfaces, 2018, 5: 1800367

17 Wang J, Liu Y, Chen X, et al. Functional metal oxides in perovskite solar cells. ChemPhysChem, 2019, 20: 2580-2586

18 Shin SS, Lee SJ, Seok SI. Metal oxide charge transport layers for efficient and stable perovskite solar cells. Adv Funct Mater, 2019, 29: 1900455

19 Haque MA, Sheikh AD, Guan X, et al. Metal oxides as efficient charge transporters in perovskite solar cells. Adv Energy Mater,
2017, 7: 1602803

20 Zhou Y, Li X, Lin H. To be higher and stronger-metal oxide electron transport materials for perovskite solar cells. Small, 2020, 16: 1902579

$21 \mathrm{Xu} \mathrm{X}$, Zhang $\mathrm{H}$, Shi J, et al. Highly efficient planar perovskite solar cells with a $\mathrm{TiO}_{2} / \mathrm{ZnO}$ electron transport bilayer. J Mater Chem A, 2015, 3: 19288-19293

$22 \mathrm{Xu}$ J, Fang $\mathrm{M}$, Chen J, et al. $\mathrm{ZnO}$-assisted growth of $\mathrm{CH}_{3} \mathrm{NH}_{3}$ $\mathrm{PbI}_{3-x} \mathrm{Cl}_{x}$ film and efficient planar perovskite solar cells with a $\mathrm{TiO}_{2} / \mathrm{ZnO} / \mathrm{C}_{60}$ electron transport trilayer. ACS Appl Mater Interfaces, 2018, 10: 20578-20590

23 Zhang $\mathrm{P}, \mathrm{Wu}$ J, Zhang $\mathrm{T}$, et al. Perovskite solar cells with $\mathrm{ZnO}$ electron-transporting materials. Adv Mater, 2018, 30: 1703737

24 Li N, Yan J, Ai Y, et al. A low-temperature $\mathrm{TiO}_{2} / \mathrm{SnO}_{2}$ electron transport layer for high-performance planar perovskite solar cells. Sci China Mater, 2020, 63: 207-215

25 Tavakoli MM, Yadav P, Tavakoli R, et al. Surface engineering of $\mathrm{TiO}_{2}$ ETL for highly efficient and hysteresis-less planar perovskite solar cell (21.4\%) with enhanced open-circuit voltage and stability. Adv Energy Mater, 2018, 8: 1800794

26 Leijtens T, Eperon GE, Pathak S, et al. Overcoming ultraviolet light instability of sensitized $\mathrm{TiO}_{2}$ with meso-superstructured organometal tri-halide perovskite solar cells. Nat Commun, 2013, 4: 2885

27 Tan H, Jain A, Voznyy O, et al. Efficient and stable solutionprocessed planar perovskite solar cells via contact passivation. Science, 2017, 355: 722-726

28 Wang X, Deng LL, Wang LY, et al. Cerium oxide standing out as an electron transport layer for efficient and stable perovskite solar cells processed at low temperature. J Mater Chem A, 2017, 5: 17061712

29 Shi X, Wu Y, Chen J, et al. Thermally stable perovskite solar cells with efficiency over $21 \%$ via a bifunctional additive. J Mater Chem A, 2020, 8: 7205-7213

30 Zhou Y, Perket JM, Zhou J. Growth of Pt nanoparticles on reducible $\mathrm{CeO}_{2}$ (111) thin films: Effect of nanostructures and redox properties of ceria. J Phys Chem C, 2010, 114: 11853-11860

31 Hu T, Xiao S, Yang H, et al. Cerium oxide as an efficient electron extraction layer for $\mathrm{p}-\mathrm{i}-\mathrm{n}$ structured perovskite solar cells. Chem Commun, 2018, 54: 471-474

32 Artiglia L, Agnoli S. Cerium oxide nanostructures on titania: Effect of the structure and stoichiometry on the reactivity toward ethanol oxidation. J Phys Chem C, 2018, 122: 20809-20816

33 Luo S, Nguyen-Phan TD, Johnston-Peck AC, et al. Hierarchical heterogeneity at the $\mathrm{CeO}_{x}-\mathrm{TiO}_{2}$ interface: Electronic and geometric structural influence on the photocatalytic activity of oxide on oxide nanostructures. J Phys Chem C, 2015, 119: 2669-2679

34 Artiglia L, Agnoli S, Paganini MC, et al. $\mathrm{TiO}_{2} @ \mathrm{CeO}_{x}$ core-shell nanoparticles as artificial enzymes with peroxidase-like activity. ACS Appl Mater Interfaces, 2014, 6: 20130-20136

35 Klasen A, Baumli P, Sheng Q, et al. Removal of surface oxygen vacancies increases conductance through $\mathrm{TiO}_{2}$ thin films for perovskite solar cells. J Phys Chem C, 2019, 123: 13458-13466

36 Wang B, Zhang M, Cui X, et al. Unconventional route to oxygenvacancy-enabled highly efficient electron extraction and transport in perovskite solar cells. Angew Chem Int Ed, 2020, 59: 1611-1618

37 Shi X, Ding Y, Zhou S, et al. Enhanced interfacial binding and electron extraction using boron-doped $\mathrm{TiO}_{2}$ for highly efficient hysteresis-free perovskite solar cells. Adv Sci, 2019, 6: 1901213

38 Caprioglio P, Stolterfoht M, Wolff CM, et al. On the relation between the open-circuit voltage and quasi-Fermi level splitting in 
efficient perovskite solar cells. Adv Energy Mater, 2019, 9: 1901631

39 Qi B, Wang J. Open-circuit voltage in organic solar cells. J Mater Chem, 2012, 22: 24315-24325

40 You J, Yang YM, Hong Z, et al. Moisture assisted perovskite film growth for high performance solar cells. Appl Phys Lett, 2014, 105: 183902

41 Shi J, Dong J, Lv S, et al. Hole-conductor-free perovskite organic lead iodide heterojunction thin-film solar cells: High efficiency and junction property. Appl Phys Lett, 2014, 104: 063901

42 Koster LJA, Mihailetchi VD, Ramaker R, et al. Light intensity dependence of open-circuit voltage of polymer:fullerene solar cells. Appl Phys Lett, 2005, 86: 123509

43 Bertoluzzi L, Sanchez RS, Liu L, et al. Cooperative kinetics of depolarization in $\mathrm{CH}_{3} \mathrm{NH}_{3} \mathrm{PbI}_{3}$ perovskite solar cells. Energy Environ Sci, 2015, 8: 910-915

44 Chen TP, Lin CW, Li SS, et al. Self-assembly atomic stacking transport layer of 2D layered titania for perovskite solar cells with extended UV stability. Adv Energy Mater, 2018, 8: 1701722

45 Li Y, Cooper JK, Liu W, et al. Defective $\mathrm{TiO}_{2}$ with high photoconductive gain for efficient and stable planar heterojunction perovskite solar cells. Nat Commun, 2016, 7: 12446

Acknowledgements This work was supported by the National Key Research and Development Program of China (2018YFB1500101), the 111 Project (B16016), the National Natural Science Foundation of China (U1705256, 51702096 and 61904053), and the Fundamental Research Funds for the Central Universities (2019MS026, 2019MS027 and 2020MS080).

Author contributions Dai S and Cai M supervised the project. Shi X conceived the original concept, designed the experiments, and wrote the manuscript. Shi X, Tao Y, and Li Z fabricated the devices and conducted the characterization and analysis with support from Peng H. Zhang $\mathrm{Z}$ provided helpful discussion during the revision process. Cai $\mathrm{M}$ and Liu $\mathrm{X}$ revised the manuscript, and all authors contributed to the general discussion.

Conflict of interest The authors declare no conflict of interest.

Supplementary information Experimental details and supporting data are available in the online version of the paper.

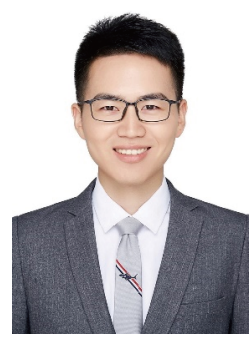

Xiaoqiang Shi obtained his BS and $\mathrm{PhD}$ degrees from North China Electric Power University in 2015 and 2020, respectively. He is currently a postdoctoral researcher at the College of Physics and Optoelectronic Engineering, Shenzhen University. His research interests include perovskite solar cells and antimony chalcogenide solar cells.

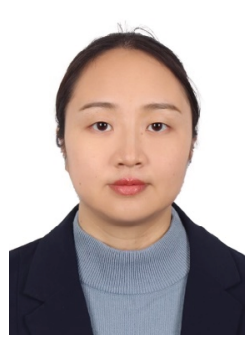

Molang Cai obtained her $\mathrm{PhD}$ degree from the Institute of Plasma Physics, Chinese Academy of Sciences in 2013. From 2013 to 2018, she successively worked as postdoctoral researcher at Queensland University of Technology and the National Institute of Materials Science, studying on efficient perovskite solar cells. In 2018, she joined North China Electric Power University as a professor. Her research interests mainly focus on efficient perovskite solar cells and in-situ measurement of photovoltaic materials and devices.

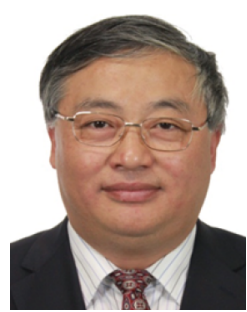

Songyuan Dai obtained his BS degree from Anhui Normal University in 1987, and MS and $\mathrm{PhD}$ degrees from the Institute of Plasma Physics, Chinese Academy of Sciences in 1991 and 2001, respectively. In 2012, he joined North China Electric Power University as a full professor. His research interests include dyesensitized solar cells, quantum-dot solar cells and perovskite solar cells.

\section{基于 $\mathrm{CeO}_{x}$ 修饰层降低界面复合损耗的光稳定钻钛 矿太阳电池}

时小强 ${ }^{1}$, 陶冶 ${ }^{1}$, 李卓芯 ${ }^{1}$, 彭会荣 ${ }^{1}$, 蔡, 墨朗 ${ }^{1,2^{*}}$, 刘雪朋 ${ }^{1}, 弓^{\circ}$ 中艳 ${ }^{1}$, 戴松元 ${ }^{1,2^{*}}$

摘要 尽管已经获得了很高的能量转换效率, 但由于非辐射复合损 失, 钻钛矿太阳电池的潜力仍未完全释放. 钻钛矿层和电荷传输层 之间的界面是发生复合损耗最多的地方. 对于低温制备的 $\mathrm{TiO}_{2}$ 电 子传输层, 其与钲钛矿层之间的界面接触和能带对准对于非辐射 复合损耗的减少来说至关重要. 在这项研究中, 我们利用 $\mathrm{CeO}_{x}$ 中间 层修饰钙钛矿 $/ \mathrm{TiO}_{2}$ 界面, 并研究了器件的电荷传输性能. 双层结构 的 $\mathrm{TiO}_{2} / \mathrm{CeO}_{x}$ 电子传输层改善了界面接触和能级匹配, 提高了电子 转移, 抑制了界面复合. 基于 $\mathrm{TiO}_{2} / \mathrm{CeO}_{x}$ 电子传输层的器件表现出 $1.13 \mathrm{~V}$ 的高开路电压和超过 $20 \%$ 的光电转换效率, 而基于 $\mathrm{TiO}_{2}$ 电子 传输层器件的开路电压仅为 $1.08 \mathrm{~V}$, 转换效率约为 $18 \%$. 此外, 基于 $\mathrm{TiO}_{2} / \mathrm{CeO}_{x}$ 电子传输层的钙钛矿器件在 $300 \mathrm{~min}$ 光照后仍能保持初 始效率的 $88 \%$, 而基于 $\mathrm{TiO}_{2}$ 电子传输层的器件几乎失效. 这项研究 为基于低温 $\mathrm{TiO}_{2}$ 电子传输层的钻钛矿太阳电池提供了一种增强转 换效率和光稳定性的有效策略. 